\title{
An Analysis On Subtitling Strategies Of Romeo And Juliet Movie
}

\author{
Endang Dwi Hastuti \\ SMA Negeri I Sumberlawang \\ hastuti.endangdwi@yahoo.com
}

\begin{abstract}
The focus of this research is to identify the subtitling strategies applied in the subtitling of Romeo and Juliet movie. This research belongs to descriptive qualitative research along with purposive sampling techniques. The objects of the research are English sentences spoken by the actors and actress in Romeo and Juliet movie as a source text (ST) and its Indonesian subtitling as a target text (TT).

The research findings show that the subtitling strategies applied in Romeo and Juliet movie are expansion, paraphrase, transfer, imitation, condensation, decimation, deletion, taming, and resignation. Among those strategies; condensation is the most dominant one due to the limited space and subtitling time appearance because in the subtitling process, there should be a thrifty translation whereas, the accuracy of Romeo and Juliet subtitling depends on the context covering the text, both situation context and cultural context. There are three components covering the situation context, namely field, mode/channel, and tenor/relation.
\end{abstract}

Key words: Subtitling Strategy, Subtitling Accuracy, Thrifty Translation 


\begin{abstract}
Abstrak
Fokus penelitian ini ialah untuk mengidentifikasi strategi subtitling yang diterapkan dalam subtitling film Romeo and Juliet. Penelitian bersifat deskriptif kualitatif dengan menggunakan teknik purposive sampling. Obyek penelitian ini adalah kalimat bahasa Inggris yang diucapkan oleh para aktor dan aktris di film Romeo and Juliet sebagai teks sumber (ST) dan subtitling Indonesia sebagai teks sasaran (TT). Hasil penelitian menunjukkan bahwa strategi subtitling yang diterapkan dalam film Romeo and Juliet ialah: ekspansi ,parafrase, transfer, imitasi, kondensasi penipisan (decimation), penghapusan, pelembutan (taming) dan pengunduran (resignation). Di antara strategi-strategi tersebut kondensasi adalah yang paling dominan karena keterbatasan ruang subtitling dan ketersediaan waktu karena subtitling harus menghasilkan terjemahan yang hemat. Sedangkan akurasi subtitling film Romeo and Juliet tergantung pada konteks yang meliputi teks, baik konteks situasi dan konteks budaya. Ada tiga komponen yang meliputi konteks situasi, yaitu lapangan, modus / channel, dan tenor / relasi.
\end{abstract}

Kata kunci: Strategi subtitling, ketepatan subtitling, terjemahan yang hemat

\title{
Introduction
}

Recently, movie translation or subtitling grows rapidly. There are two kinds of movie translation namely: dubbing and subtitling which have differences in both. Bordwell and Thompson (1990: 409) said "The most two common forms of screen translation are dubbing and subtitling”. Then he said further "Dubbing is the process of replacing part or all of the voices on the sountrack in order to correct mistakes or rerecord dialog". It means that a dubbing is a process to replace voice in "soundtrack" to correct the mistakes and re-record the voice. Thomson also said that dubbing can also be applied not only from Source Language (SL) into Target Language (TL) but, it also can be applied from Source language 
(SL) into source language (SL) with the difference voice. Another translation expert, Whereas, Chitas, also explored the definition of "dubbing" as follow: "Dubbing involves replacing the original soundtract in the actor's dialogue with a target language (TL) recording that reproduces the original message, while at the same time ensuring that the $T L$ sound and the same actors' lip movements are more or less synchronized (2003:15)". This definition stresses that dubbing involves replacing the "soundtrack" from SL into TL with the same lips movement from the actors.

Subtitling is truly different from dubbing. Gambier (1993: 276) explored his definition about subtitling as follow: "Subtitling is one of two possible methods for providing the translation of a movie dilaogue, where the original dialogue soundtrack is left in place and the translation is printed along the bottom of the film". In other words, it can be said that subtitling is done by translating the film's dialogues then put the printed translation in the bottom of the film. Similarly as dubbing, the purpose of subtitling is helping the viewers enjoy the films such as documenter movies, drama, and action and so on. Then Betty White in (file:///G:/subtitling/eotvsection.php.htm updated./04/01/2011) stressed that the amount lines of subtitling is not more than two lines.

From the definition of dubbing and subtitling above, it can be concluded that "dubbing" is the replacement of the original soundtrack of source language (SL) into target language (TL) whereas "subtitling" is done by sticking the written translation (target language) on the movie monitor. Dubbing and subtitling are one of translation great works. Firstly, they are done with translation process, and then continued by recording process or sticking process. 
The work of subtitling is done by having "texts" at first. The meaning of the "text" depends on the situation context and cultural context. Situation context is composed by some variables such as field (content), mode/channel (spoken text/written text), and tenor/relation (the relation between the speaker and the listeners/viewers or the writer and the reader). Knowing the situation context and cultural context is very important in subtitling process because by having them the translator can transfer the message from the source text into target text well and he/she be able to choose the appropriate translation strategies in doing his/her works. From those phenomenon, this research focuses on (1) the equivalent meaning on subtitling of Romeo and Juliet movie viewed from the context situation and cultural situation covered the text, and (2) the translation strategies applied by the translator in translating Romeo and Juliet movie.

\section{The Definition of Translation}

There are some translation definitions explored by the experts of translation. Some of them are Catford (1965), Nida and Teber (1974) and Larson (1984). Catford (1965: 1) defined the translation as "an operation performed on language: a process of substituting a text in one langauge for a text in another". Nida and Taber (1974) said that translating consist of reproducing in the receptor language to the closest natural equivalent of the source language message, at first in meaning and secondly in term of style. While Larson (1983: 17) saw that translation is the replacement of meaning from source language (SL) into target language (TL) by using the form of the receptor target language. From the definition of translation above, it can be concluded broadly, translation focuses on meaning equivalent. 


\section{Meaning (Situation Context and Cultural Context Based)}

Neubert (1984) in Bell (1991: 79) said that meaning is "the kingpin of translation studies. Without understanding what a text to be translated means for L2 users the translator would be hopefully lost". From this definition it can be inferred that meaning has a broad definition. When we are talking about "meaning" it means that we are not only talking about linguistics aspect but also talking about everything outside the linguistics aspects such as culture, situation, norm and rule of the society using that language.

The meaning of the text depends on the situation context and cultural context. There are three components composed the situation contexts, namely: field (content), mode/channel (written/spoken text), tenor/relation (the relation between speaker-hearer/viewer) (Riyadi Santoso, 2003: 21). The meaning of the text is also influenced by the culture covering the text whether explicitly or implicitly. Explicitly, culture is a kind of artifact produced by the society such as clothes, foods, technology etc., while implicitly, and culture appears in the forms of belief, attitude, values and norms.

\section{Subtitling Important Rules}

Sugeng Hariyanto (2005: 100) said that there are some important rules in subtitling such as the plot work, the movie terms, script and movie as a whole work. Further, he said that "plot work" in subtitling means translating the movie script from the source language into target language, then combine the translation result with the movie and then revise it. Besides that, there are some terms that should be known by the movie 
translator or subtitler such as frame, shot, scene and sequences. Frame is a basic unit of the movie that is a set of shot; then some shots are combined into scene; some scenes are combined into scuents; and the last, some scuents combined into movie which are connected by the dialogues. Besides, subtitling is also composed by movie components such as soundtrack, music, effects, the tone of the actors, mimic and gesture, camera movement, distance, and montage (cuts, fade-in, dissolve, and so on).

Movie script refers to the source text that will be translated into target text. There two kinds of scripts namely the original script and script purposed to the movie translator. There are some notes for the original script such as the setting notes, actor's mimic, and so on. The advantage of having original script is that the translator knows "the situation" well. Whereas the script proposed to translator does not include such notes but it includes the "timing" notes which help in deciding the subtitling appearance in the movie monitor. Movie as a whole work means that movie is the same as novel covered by certain society culture that makes the translator works harder because the translators must transfer the semantic and pragmatics meaning, and also the culture.

\section{The Subtitling Difficulties}

Translating a movie is not an easy work. Sugeng Haryanto (2005) said that in translating a movie, the translator usually get difficulty in 'language and culture'. Language difficulty refers to culture reference, idioms, diction, humor and pragmatics meaning. Whereas culture difficulty refers to the lack of knowledge and experience that the translator has related to the culture habits done by the SL society. It also happens 
when the translator translates idioms where they should choose the appropriate diction. It is very difficult to translate an idiom because the limitedness equivalent meaning between source language and target language. Then, the next problem that the translator has is related to humor teasing allusion and pragmatics meaning. Sometimes, the translator doesn't realize that the text which he/she translates contain the implicit humor teasing allusion or the translator doesn't find the appropriate equivalent meaning in target language because the meaning of the humor related to the source language culture. While the difficulty in pragmatics meaning means the difficulty in finding the appropriate equivalent related to the actor's relation in composing dialogue especially when the dialogues use certain dialect.

Sugeng Haryanto (2005) said further that movie translator also gets difficulties because of limited time appearance and limited layout. There are some subtitling layout rules such as the translation should be at the monitor buttom, it just contains 2 lines in maximum, it only contains 35 characters for each lines, it must be Helvetica or Arial font without sheriff, the font color and the background must be in white, the text position is in the middle, and it must be right flat for the dialogue beginning without a dash.

\section{Subtitling Strategies}

Strategies here mean techniques used by translator in translating word, phrase or speaker's utterance. Sugeng Haryanto (2005: 103) explored 10 subtitling strategies as follows: 


\section{Expansion}

Expansion means giving addition meaning in the target language. For example, the sentence that's in the dead day is translated into "Itu terjadi di bebek mati (hari itu, seekor bebek mati kena lemparan rotiku)".

2. Paraphrase

In this strategy, the translator gives more explanation toward the part of the sentence based on his/her own opinion. For example, the sentence "Turn back no longer" is translated into "Jangan lagi melihat masa lalu”.

3. Transfer

Transfer strategies are done by translating the source text literally. For example, the sentence "Turn back no longer" is translated into "Jangan lagi melihat-lihat ke belakang".

4. Imitation

Imitation strategies are done by rewriting the source text into target text. Usually this strategy is done in translating the name of person or the name of place.

5. Transcription

This strategy is done by rewriting the certain words because of the textual function how that language should be. For example, how the sentence in the source text pronounced can be seen in the subtitling.

6. Condensation

Condensation strategy is done by shortening the source text. In this strategy the subtitler or translator eliminates unimportant utterance. 
But, usually this strategy can make the loosing of pragmatics effect that actually it should be transferred into target language

7. Decimation

Decimation is an extreme condensation. This strategy is usually used in translating the actors' conversation or utterance when they have a quarrel especially when they speak loudly and with fast speed.

8. Deletion

Deletion strategy means some of source texts are deleted because the translator/subtitler believes that those parts are not important. The differences between deletion and condensation is that in condensation there is no any part that be deleted or it's just be condensed but in deletion strategy there are some parts that be deleted by the translator.

9. Taming

Taming strategies is used to translate the rude or taboo words in order to be acceptable in target language.

10. Resignation

Resignation is done when there is no any solution in transferring the message from SL into TL. Automatically, the meaning of the source text is not transferred into target language, or in other word it is "untranslatable".

\section{Research Methodology}

This research belongs to descriptive qualitative research with the aim to describe the certain cases. The data in this research are the translation 
units in lingual forms of Romeo and Juliet Movie such as words, phrases and clauses whereas, research procedures refer to a set of work in the research. Research procedure is a map on how the research should be done, how to do it, and why it is done. The researcher procedures belong to this research are data collecting, data analysis technique, and presentation stage.

The object of the research is English Romeo and Juliet movie as the source text (ST) and the Indonesian subtitling of Romeo and Juliet Movie as the target language (TT). This research is done with the assumption that Romeo and Juliet Movie is one of Shakespeare's masterpiece works and this movie is one of Media to communicate between the author and the readers/viewers. The data in this research is parallel bilingual corpus consisting of spoken text spoken by the actors and actress in Romeo and Juliet Movie as the source text (ST) and Indonesian subtitling appear in the monitor as the target text (TT).There are some steps done in analyzing the data. At first, the researcher focuses on identifying the source text meaning profile and the equivalent meaning in target text then analyzing the equivalent meaning based on the situation context and cultural context. Then, the second analysis is focused on the subtitling strategies used in Romeo and Juliet subtitling. The last stage of this research is composing and presenting the result of the research. This research uses qualitative analysis strategy. In presentation stage, in making the conclusion (verification) the researcher is always eager to make clarification by having discussion with her colleges toward the truth test of the meaning appears in the data. 


\section{Discussion}

Language always appears in the form of "text". The text's appearance is surrounded with its society, whether physic or non-physic, which supports the text existence or it can be said that a text always appears in its context. As explained before, there are two kinds of contexts surrounding the text, namely situation context and cultural context. There are three variables composing the situation context, namely field, tenor, and mode. Below are the examples of the influence of situation context and cultural context toward Romeo and Juliet movie translation.

Example

SL: Romeo : But soft! What light through younder window breaks? It is the east, and Juliet is the sun Arise, fair sun, and kill the envious moon Who is already sick and pale with the grief That thou her maid art far more fair than she But not her maid, since she is envious Her vistal livery is but sick and green And none but fools do wear it; cast it off It is my lady, $O$ it is my love

TL: Romeo: Tapi lembut. Cahaya apa dari jendela itu Itu di timur dan Juliet adalah matahari Bangkitlah matahari dan bunuh bulan pengiri tu Yang telah sakit dan pucat

Karena kau lebih cantik darinya

Jangan ikuti dia, karena ia iri hati menerimanya

Begitu irinya dan hanya si dungulah yang

Keluarlah

Itulah kekasihku

Dia menyadari itu 
The description of situation context of prologue above is as follow. The above prologue is spoken by Romeo in a night after having a party held by Capulet family. In that party, Romeo met Juliet for the first time and they both fall in love. After the party ends, Romeo tries to enter Juliet's chamber by climbing the high wall fences. After reaching the Capulet's house, Romeo is busy to find out Juliet's chamber, when he finds it; he speaks as the above prologue. The tenor of this text is that Romeo who falls in love to Juliet after he meets Juliet for the first time. Juliet is a girl who makes Romeo's away from Rosaline's love. The mode of this text is spoken text which is spoken softly and full of feeling companied by soft music instrument. While the cultural context of this text is that when someone is falling in love, he or she would do everything although it is outside their capability; just want to meet with the person whom he or she falls in love with. Furthermore, sometimes he or she does a silly thing and annoy people's life just want to prove that he or she really loves his or her partner.

There are some interesting things toward those subtitling/translation. The first, the translation of the sentence "It is the east, and Juliet is the sun" which is translated into "Itu di timur dan Juliet adalah matahari". Actually, the source text is the conditional sentence in which the word "if" is implicated so, the clause "It is this east" has a meaning "Andai itu timur". Secondly, the clause "That thou her maid art" is not translated by the translator. Actually, the phrase "her maid" relates to western culture having a meaning "the servant of Diana, the virgin goodness of the moon, was unmarried maidens". The Europeans believe that "Dewi Bulan" has a faithful maid named Diana who never got married during her life and gave her whole life to Dewi Bulan. Thirdly, the translation of the sentence 
"And none but fools do wear it; cast it off" which is translated into "Begitu irinya dia hanya si dungulah yang menerimanya". We can see that this translation is influenced by the situation context. The situation context composes this clause is that Romeo is truly falling in love with Juliet, so he thinks that just a fool person goes to Diana's thinking (Dewi Bulan's maid) who decides to be unmarried woman during her life. Fourth, the translation of the sentence "It is my lady, $O$ it is my love" which is translated into "Keluarlah, itulah kekasihku". When we pay attention more to that translation it seems that the meaning of target language is totally different from the meaning of source language. The translator fails to transfer the meaning of the clause "It is my lady". The translation is influenced by the situation context that Romeo truly wanted to meet Juliet that night so he really hoped that Juliet came out her chamber when Romeo saw Juliet's shadow. Fifth, the translator also fails to translate the sentence "O that she knew she were" which is translated into "Dia menyadari itu". Actually this sentence has a purpose that is Romeo hopes; Juliet knows that she is Romeo's lover now.

\section{Subtitling Strategies}

As explained before, subtitling strategies here mean techniques used by the translator in translating word, phrase or speaker's utterance. It's very possible that one sentence is translated by using one or more translation strategies. There are 10 subtitling strategies that can be applied in subtitling, namely: expansion, paraphrase, transfer, imitation, transcription, condensation, decimation, deletion, taming, and resignation

a. Expansion 
The followings are the examples of translation using expansion strategies.

1. SL: Narator : In fair Verona, where we lay our scene.

TL: Narator : Di Verona yang indah, dimana kami bercerita

2. SL: Sampson : I will bite my thumb at them which is disgrace to them if they bear it.

TL: Sampson : Kugigit jempolku sebagai tanda memperlakukan mereka jika mereka tahan. Majulah aku akan $\underline{\text { mendukungmu }}$

In the first sentence, "In fair Verona, where we lay our scene" and it is translated into "Di Verona yang indah, diamana kami bercerita". Here, we can see that the translator gives more explanation by adding the phrase "yang indah". It is done because the movie shows the view and the description about Verona that looks so beautiful, clean, metropolis city full of citizen's joys. While in the second example, expansion strategies appear by adding explanation in the sentence "Majulah, aku akan mendukungmu". The addition of this sentence has a purpose to clarify the meaning of the clause "I will bite my thumb at them". This clause, culturally has a meaning "an action which indicated contempt or defiance" or a kind of action to mock somebody else. The adding of the sentence "Majulah, aku akan mendukungmu" has a purpose that Sampson endorses his friends to fight with the Capulets.

b. Paraphrase

The followings are the examples of paraphrase strategy:

1. S1 : I'll look to like, if looking like move

TL :Aku akan melihatnya dulu untuk memastikan apa aku mencintainya 
2. SL : This is the matter. Nurse, give leave a while

We must talk in secret. Nurse comes back again

I have remembered me, thou's hear our counsel

Thou know'st my daughters of a pretty age

TL : Suster biarkan kami sendiri

Kami harus bicara empat mata. Suster, kembalilah $\mathrm{Aku}$ baru mengingatkan diriku. Dengar percakapan kami

Suster, kini kau tahu putriku mulai menjadi remaja $\underline{\text { cantik }}$

The paraphrase strategies appear in the first sentence that is in the phrase "if liking moving to move" which is translated into "untuk memastikan apa aku mencintainya". The sentence "“'I'll to look like, if looking liking move" has a meaning if just by seeing it can make someone falls in love, then Juliet wants to see Paris at first with the hope that she can fall in love to Paris as what her mother hopes. In the second sentence, the paraphrase strategy appears in the translation of the sentence "We must talk in secret" which is translated into "Kami harus bicara empat mata" and the sentence "Thou know'st my daughters of a pretty age" which is translated into "Suster, kini kau tahu putriku telah menjadi remaja cantik". The phrase "in secret" has a meaning "rahasia" and the translator paraphrases into "empat mata". Whereas the phrase "of pretty age" has the same meaning with "at an attractive age" that is the changing of people's growth from a child into teenager or in Indonesian it's famous with ABG (Anak Baru Gede) in which at this age a girl usually looks more attractive and charming. 
c. Transfer

The followings are the examples of transfer strategy:

1. SL: Romeo : Well what was yours?

Mercutio : That dreamers often lie

TL: Romeo : Dan apa mimpimu?

Mercutio : Pemimpi sering berbohong

2. SL: Romeo : Peace, Mercutio, peace!. You talk of nothing Mercutio : $\underline{\text { True, I talk of dreams }}$

TL: Romeo : Tenanglah Mercutio, tenang. Kau Cuma mengada-ada.

Mercutio : Benar, aku bicara tentang mimpi

3. SL: Romeo : My lips, two blushing pilgrims, ready stand To smooth that rough touch with a tender kiss

TL: Romeo : Bibirku seperti dua musafir, siap untuk Melembutkan sentuhan kasar itu dengan ciuman lembut

Let's pay attention more to the underlined sentences above. At those sentences, it's clear that the translator translates those sentences literally, without giving more explanation or point of view changing. In the first sentence, the translation of the sentence "That dreamers often lie" is translated into "Pemimpi sering berbohong". The word "lie" means "tell lie" or in Indonesia it's equivalent with "pembohong/pendusta". In the second example, the clause "Peace, Mercutio, peace!" and "True, I talk of dreams" which each clauses is translated into "“Tenanglah Mercutio, tenang" and "Benar, aku bicara tentang mimpi". Here, it's so clear that the translator only transfers the meaning of source language into target language literally. The same case also happens in third example "My lips, two blushing 
pilgrims, and ready stand. To smooth that rough touch with a tender kiss" which's translated into "Bibirku seperti dua musafir, siap untuk melembutkan sentuhan kasar itu dengan ciuman lembut".

d. Imitation

Below are the examples of imitation strategy.

1. SL: Sampson : A dog of the house of Montague move me TL: Sampson : Anjing di rumah Montague membuatku marah

2. SL: Narrator : In fair Veronna where we lay our scene TL: Narator : Di Verona yang indah dimana kami bercerita

3. SL: Lady Montague : O where is Romeo? Saw you him today? TL: Lady Montague : Dimana Romeo? Kau melihatnya tadi?

As it has explained previously, imitation strategy is done in which the translators rewrite the source text into target text as what it is. This strategy is usually applied in translating the name of person or the name of place. In the above example, we can see that the translator just brings the word Montague, Verona, and Romeo into target text without changing its phonemes or its writing.

e. Transcription

This strategy is done by re-writing the use of certain words to fulfill the textual function about how the language should be used. But, in this research the researcher doesn't find the using transcription strategy.

f. Condensation

The followings are the examples of condensation strategy. 
1. Sl: Nurse : Now, by my maidenhead at twelve years old. I bade her come. What , lamb! What lady bird. God Forbid! Where is the girl? Juliet

TL: Nurse : Aku akan memanggilnya. Tuhan melarang. Juliet......

2. SL: Capulet : Trust to it, bethink you, I'll not be forsworn

TL: Capulet : Percayalah. Pikirkanlah

3. SL: Clown : Madam, the guest are come supper served up, you called

TL: Clown : Nyonya, para tamu telah hadir

Condensation strategy is applied by summarizing the useless sentence or utterance. In the first sentence, the translator condenses the sentence "Now, by my maidenhead at twelve years old. What, lamb! What lady bird. Where is the girl?" in the target text. Actually, the sentence "What, lady-bird! God forbid! "What, lamb! What lady bird" has a meaning the Nurse asks Juliet to come. The Nurse uses the phrase "lady bird" means "woman of bad reputation" so, the use of phrase "God forbid" means that Juliet should not be such kind of that girl. Furthermore, that sentence is translated by using condensation strategy because the Nurse speaks so loudly and fast.

In the second example, condensation appears in the sentence "I'll not be forsworn". In this case, the condensation is done because this sentence is spoken fast and loudly. This quarrel happens because the speaker (Capulet) is getting angry because of Juliet's refusal toward Paris' proposal. In the third sentence, "Madam, the guests are come supper served up, you called" which is translated into "Nyonya, para 
tamu telah hadir", the condensation in this translation appears in "supper served up and you called". Although the translator condenses those clauses in the translation, but the viewers understand the message because in the screen also presented the served meals on the table and all the guests are ready with the party.

\section{g. Desimation}

The followings are the example of decimation strategies.

1. SL: Tybalt : What, drawn, and talk of peace? I hate the word TL: Tybalt : Damai? Aku benci kata itu

2. SL: Tybalt : Have at thee, coward

TL: Tybalt : Majulah, Ayo

3. SL: Sampson : Quarrel. I'll back thee. Nay, as they dare TL: Sampson : Berkelahi aku akan mendukungmu

In the first example, the decimation appears when the translator translates the sentence "“"What, drawn, and talk of peace" which is translated into “damai?". It means that there is an extreme condensation which's called decimation. This utterance is spoken by Tybalt when he gets a quarrel with the Motagues family named Benvolio. The same cases also appear in the second and third examples. The second and third examples literally have meanings "Majulah kalian semua, pengecut", but the translator condenses it into "Majulah, Ayo". while in the sentence "Quarrel. I'll back thee. Nay, as they dare" and translated into "Berkelahi aku akan mendukungmu", condensation strategy appears when translator condenses the meaning of the clause 
"Nay, as they dare" which's literally has a meaning "Jika mereka berani".

h. Deletion

The followings are the examples of deletion:

1. SL: Juliet : Come, gentle night; come loving, black-browed night

TL: Juliet $\quad$ : Datanglah malam. Datanglah malam penyayang

2. SL: Benvolio : Put up your sword, you know not what you do?

TL: Benvolio : Kenakan pedangmu!

In the first example, the translator deletes the phrase "blackbrowed" in the translation. Actually that phrase is modifier of the word "night" so it becomes a noun phrase which the word "night" is the head and the phrase "loving black-browed" is the modifier which modifies the word "night". There is also an interesting thing toward that translation that is the translator translates the word "lovely" into "penyayang" which's unacceptable in target language. The word "lovely" is equivalent with "bagus, menyenangkan, elok, indah". So, the translation of the phrase "comes loving, black-browed night" should be "Datanglah malam kelabu yang indah."

In the second example, the translator also makes deletion in doing the subtitling. The deletion appears when the translator deletes the sentence "you know not what you do". That sentence is spoken by Benvolio proposed to Tybalt when they both are in a quarrel between the Montague followers versus Capulet followers. Literally, that sentence has a meaning “Tak taukah kau apa yang harus kau lakukan?”. 
This utterance has an implicit meaning in order that Tybalt takes out his sword and gets ready to have quarreled with Benvolio.

i. Taming

Below are the examples of taming strategy.

1. SL: Lady Capulet : Fie, fie! What are you mad?

TL: Lady Capulet : : Sudah, hentikan

2. SL: Romeo : :Tush, thou are deceived

TL: Romeo : Diam, pergilah kau

Those sentences are spoken by the speakers who are getting angry. Then the translator translates the sentences by using taming strategies in order to be more acceptable and polite in target language culture. Literally, those sentences can be translated into "Hentikan, kau sudah gila/tidak waras" while the second sentence is "Enyahlah, kau pembohong".

j. Resignation

Below are the examples of resignation strategies.

1. SL: Lady Capulet: Well, think of marriage now. Younger than you Here in Verona, ladies of esteem Are made already mothers I was your mother much young these years

TL: Lady Capulet: -

Seingatku, aku melahirkanmu saat aku seusiamu

2. SL: Mercutio : Athawart men's noses as they lie asleep Her wagon spokes made long spiders' leg The covert of the wings of grasshoppers Her traces of the smallest spider-web 
TL: Mercutio : Dari hidung pria saat mereka tidur Keretanya bagai lemari kosong

In the first example, the translator doesn't translate the sentence "Well, think of marriage now. Younger than you. Here in Verona, ladies of esteem are made already mothers". Those sentences are spoken by Lady Capulet when she persuades Juliet in order to get married with Paris, a rich and an honorable man from Veronna. Literally, those sentences can be translated into "Berfikirlah untuk $\underline{\text { menikah. Banyak gadis di Verona lebih muda darimu dan sudah }}$ menjadi ibu".

The second example, the translator also doesn't translate the sentence "The covert of the wings of grasshoppers. Her traces of the smallest spider-web". Those sentences are spoken by Mercutio when he speaks to Romeo and they both tell about their own dreams. Those sentences are spoken by Mercution with low speech as though he were still in his dream. In his dream, Mercutio met Queen Mab, a fairy who always presents in someone imagination when he/she is falling in love. Actually, those sentences can be translated into "Kerudung keretanya bagaikan sayap-sayap belalang. Jejak keretanya bagaikan sarang labalaba".

\section{Conclusion}

From the above explanation it can be concluded that the subtitling strategies applied in the subtitling of Romeo and Juliet movies are expansion, paraphrase, transfer, imitation, condensation, decimation, deletion, taming, and resignation. Among those strategies condensation is 
the most dominant one due to limited space and limited subtitling time appearance because in subtitling it must be thrifty translation.

The accuracy of subtitling in Romeo and Juliet Movie depends on the context covering the text, whether situation context or cultural context. There are three components or variables covering the situation context, namely: field, mode/channel, and tenor. It means that the translator must have cross culture understanding in order to transfer the source language message into target text well.

\section{References}

Basnnett, Susan and Andre Lefevere. 1995. Translation, History and Culture, USA: Cassell.

Bell, Roger T. 1991. Translation and Translating: Theory and Practice. London: Longman.

Bordwell, Favid and Kristin Thompson. 1990. Film Art. USA: Mc GrawHill, Inc.

Catford, J.C. 1965. A Linguistic Theory of TranslationI. London: Oxford University Press.

Cintas, Whereas. 2005. "The Viewer as the Focus of Subtitling". Translation Journal. URL: http://accurapid.com/journal/32film.htm. updated on:12/26/2010.

Gambier, Yves. 1993. "Audio Visual Communication: Typological Detour". Teaching Translation and Interpreting 2. Philadelphia: John Benjamin.

Haryanto, Sugeng. 2005. "Subtitling: Di antara Keterbatasan BahasaBudaya dan Media". Collection of International Conference on Translation:Translation, Discourse and Culture. Program Pascasarjana: UNS. 
Hoed, Benny H. 1992. Linguistik, Semiotik, dan Kebudayaan Kita. Pidato Pengukuhan Guru Besar pada Fakultas Sastra Universitas Indonesia.

Houbert, Frederic. 1998. "Translation as Communication Process" dalam Translation Journal and the Authors 1998 Volume 2, No. 3 July 1998; Available from URL:http://accurapid.com/journal/htm. updated on: 12/26/2010

Larsen. 1993. "The Subtitling of Film: Reaching Another Community". Translation Journal, URL: http://accurapid.com/journal/32film.htm. updated on:12/26/2010.

Larson, Mildred L. 1998. Meaning Based Translation: A Gude to CrossLanguage Equivalence. (Second Edition). USA: University Press of America, Inc.

Moeliono, Anton. (1995). Implikasi Penerjemahan dalam Pengembangan Bahasa Indonesia. Proyek PS2PT. DIKTI.

Nida, Eugene (1964). 2000. "Principles of Correspondence" dalam Lawerence Venuti (Ed). The Translation Studies Reader, pp.126147. New York: Routledge.

Nida, Eugene. 1975. Componential Analysis of Meaning. The Hague Paris: Mouton.

Nida, Eugene and Charles Taber. 1974. The Theory and Practice of Translation. Leiden: E.J. Brill.

Santoso, Riyadi. 2003. Semiotika Sosial Pandangan Terhadap Bahasa. Surabaya: Pustaka Eureka \& JP Press.

White, Betty. 2008. "Subtitling: The Museum of Broadcast Communication". Translation Journal, URL: http://accurapid.com/journal/32film.htm. updated on:4/1/2011.

Widodo, Erna dan Mukhtar. 2000. Kontribusi ke Arah Penelitian Descriptif. Yogyakarta: Avyrous. 